\title{
PENGARUH TIPE KEPRIBADIAN TERHADAP SELF-DISCLOSURE PADA DEWASA AWAL PENGGUNA MEDIA SOSIAL INSTAGRAM DI KOTA BANDUNG
}

\author{
Alya Zachra Fauzia, Sri Maslihah, dan Helli Ihsan \\ Fakultas Ilmu Pendidikan, Universitas Pendidikan Indonesia \\ J1. Dr. Setiabudhi N0. 229, Sukasari, Bandung, Indonesia 40152 \\ Email : alyazachra@student.upi.edu
}

\begin{abstract}
ABSTRAK. Media sosial sebagai salah satu sarana komunikasi, selain dimanfaatkan untuk berbagi informasi dan inspirasi juga seringkali digunakan sebagai sarana pengungkapan diri. Fenomena yang sedang terjadi saat ini pada pengguna instagram, diantaranya mereka seolah tak segan untuk mengungkapkan semua problematika yang sedang dihadapi di Instagram. Penelitian ini bertujuan untuk mengetahui pengaruh tipe kepribadian terhadap self-disclosure pada dewasa awal pengguna instagram di Kota Bandung. Pendekatan penelitian yang digunakan dalam penelitian ini adalah kuantitatif dengan metode analisis regresi linear sederhana. Jumlah partisipan yang terlibat dalam penelitian ini adalah sebanyak 400 orang dewasa awal pengguna instagram. Instrumen yang digunakan dalam penelitian ini adalah Revised Self-Disclosure Scales (RSDS) untuk mengukur self-disclosure dan Eysenck Personality Questionnaire Brief version (EPQ-BV) untuk mengukur tipe kepribadian. Analisis data pada penelitian ini menggunakan regresi linear sederhana. Hasil yang diperoleh menunjukan bahwa terdapat pengaruh yang signifikan tipe kepribadian terhadap self-disclosure. Extraversion dan neuroticism memiliki pengaruh yang signifikan terhadap self-disclosure pada dewasa awal pengguna instagram di Kota Bandung. Dengan kata lain, tipe kepribadian merupakan faktor yang dapat mempengaruhi pengungkapan diri seseorang terutama ketika sedang berkomunikasi menggunakan media sosial.
\end{abstract}

Kata kunci: Tipe Kepribadian; extraversion; neuroticism; self-disclosure; media sosial; instagram

\section{THE INFLUENCE OF PERSONALITY TYPES ON SELF-DISCLOSURE IN EARLY ADULTS OF I NSTAGRAM USERS IN BANDUNG}

\begin{abstract}
Social media as a means of communication, besides being used to share information and inspiration, is also often used as a means of self-disclosure. The phenomenon that is happening right now for Instagram users, including them seems to not hesitate to reveal all the problems that are being faced on Instagram. This study aims to determine the effect of personality types on self-disclosure in early adults of Instagram users. The research approach used in this study is quantitative with a simple linear regression analysis method. The number of participants involved in this study were as many as 400 early adult users of Instagram. The instrument used in this study was Revised Self-Disclosure Scales (RSDS) to measure self-disclosure and the Eysenck Personality Questionnaire Brief version (EPQ-BV) to measure personality types. Data analysis in this study used simple linear regression. The results obtained show that there is a significant influence on personality type on self-disclosure. Extraversion and neuroticism have a significant effect on self-disclosure in early adults of Instagram users. The recommendation for further researchers is to add other variables that can influence self-disclosure and use other methods. In other words, personality type is a factor that can affect one's self-expression, especially when communicating using social media.
\end{abstract}

Keywords: Personality types; extraversion; neuroticis; self-disclosure; social media; instagram

\section{PENDAHULUAN}

Penggunaan internet terutama pada media sosial semakin meningkat digunakan oleh masyarakat. Berdasarkan informasi dari Asosiasi Penyelenggara Jasa Internet Indonesia (APJII) tahun 2017, jumlah pengguna internet di Indonesia mencapai 143,26 juta jiwa, angka tersebut meningkat dibandingkan pada tahun 2016 yang tercatat mencapai 132,7 juta jiwa. Sebagaimana dikutip dari harian online tekno.kompas.com (2018) bahwa perkembangan Internet semakin pesat sejak muncul situs jejaring sosial seperti facebook, twitter, instagram dan sebagainya. Lebih lanjut lagi, rata-rata orang Indo- nesia menghabiskan 3 jam 23 menit sehari untuk mengakses media sosial.

Media sosial memiliki beberapa fungsi untuk memenuhi kebutuhan individu diantaranya, membangun hubungan sosial melalui dunia maya, menyampaikan apa yang dialami dan dirasakan individu, serta segala hal yang dapat dituangkan di jejaring sosial (Weiser, 2001). Media sosial sebagai salah satu sarana komunikasi, selain dimanfaatkan untuk berbagi informasi dan inspirasi juga seringkali digunakan sebagai sarana ekspresi diri, pencitraan diri, serta sebagai sarana berkeluh kesah (Oktavianti, 2018). Hal ini juga berlaku pada media sosial instagram. Instagram merupakan aplikasi jejaring sosial 
berbasis foto dan video yang memungkinkan penggunanya dapat mebagikan konten apapun kepada publik. Tujuan dari dibuatnya instagram agar pengguna dapat selalu terhubung dengan orang lain serta menjadi wadah untuk mengekspresikan diri melalui foto atau video yang bagikan (Hasan, 2016).

Berdasarkan penelitian yang dilakukan oleh Rizkia (2017), instagram menjadi aplikasi jejaring sosial yang paling banyak digunakan, sebesar 82 persen, meninggalkan Facebook yang sebesar 66 persen. Indonesia sendiri menjadi negara dengan pengguna instagram terbesar seAsia Pasifik (Bohang, 2017). Sebagaimana dikutip dari media masa liputan6.com (2016) mayoritas pengguna instagram yang aktif didominasi usia 18-24 tahun dengan presentase 59 persen. Sementara, pengguna dengan usia 25-34 tahun sebanyak 30 persen, dan usia 34-44 tahun berada di angka 11 persen. Berdasarkan fakta tersebut, usia pada masa dewasa awal menduduki pengguna aktif terbanyak se-Indonesia.

Penggunaan media sosial seperti instagram tidak selamanya dianggap baik, karena dapat menimbulkan masalah seperti menyebarluaskan informasi diri secara berlebihan bahkan pada orang tidak dikenal sekalipun, sehingga dapat mempermudah pihak-pihak yang mempunyai maksud kurang baik (Anwar, 2017). Karena pada hakikatnya dalam bermedia sosial, seseorang dapat menentukan informasi apa yang ingin ia sampaikan, kapan ia ingin mengungkapkan informasi tentang dirinya, bagaimana informasi itu disampaikan, serta kepada siapa informasi itu akan disampaikan.

Istilah dalam psikologi yang menjelaskan mengenai kegiatan membagi atau menyampaikan informasi diri kepada orang lain dinamakan dengan self-disclosure (Hasan, 2016). Self-disclosure yaitu kegiatan membagi informasi diri kepada orang lain berupa informasi perilaku, sikap, perasaan, keinginan, motivasi, serta ide yang terdapat dalam diri individu (Dayakisni \& Hudaniah, 2009). Wheeless, dkk (1986) menjelaskan bahwa pengungkapan diri merupakan bagian dari referesni diri yang dikomunikasikan dan diberikan individu secara lisan pada suatu kelompok. Konsep self dislcosure sendiri adalah cara untuk menunjukkan siapa kita dan mengungkapkan kebutuhan kita (Leung, 2002). Menurut Ekasari (2013) dengan adanya self-disclosure seorang individu dapat mengungkapkan pendapatnya, perasaannya, cita-citanya dan sebagainya. Seiring dengan berjalannya waktu, self-disclosure yang biasanya dilakukan dengan bertatap muka langsung, saat ini bertranformasi untuk cenderung melakukannya pada media sosial. Menurut Boyd dan Heer (2006) self-disclosure dalam media sosial bermanfaat sebagai sarana dalam mempresentasikan identitas diri.
Kenyataan dari self-disclosure saat ini, banyak masyarakat terutama remaja dan dewasa awal, berbeda pengungkapan dirinya pada dunia nyata dengan media sosial khususnya instagram. Dari hasil jajak pendapat sebuah televisi swasta Amerika Serikat terhadap 2000 orang menyatakan bahwa setengah diantaranya setuju jika media sosial dijadikan sebagai tempat untuk mengeluarkan unek-unek terutama hal bersifat negatif. Lebih lanjut lagi, sebanyak 52\%, tujuan seseorang curhat di jejaring sosial untuk mendapatkan simpati dari orang lain. Sedangkan 30\% ingin meluapkan kemarahannya, bisa karena dendam, iri ataupun cemburu (Liputan6. com, 2012). Konteks self-disclosure pada media sosial secara umum mencakup cara orang berbagi informasi dalam bentuk status, foto/video, chatting, komentar dan lain sebagainya.

Hakikatnya, self-disclosure merupakan hal penting bagi individu yang khususnya yang memasuki tahap dewasa awal, karena pada masa tersebut individu membutuhkan sarana untuk membangun hubungan sosial dengan orang lain (Hurlock, 2003), serta untuk kebutuhan eksistensi diri (Nurdania, 2013). Akan tetapi berdasarkan hasil survey yang dilakukan peneliti pada pengguna instagram memberikan data bahwa ditemukan sejumlah masalah pada pengguna instagram diantaranya mereka seolah tak segan untuk mengungkapkan semua problematika yang sedang dihadapi di Instagram. Responden juga sering mem-posting mengenai aktivitas sehari-hari yang sedang dijalani, hobi, pengalaman pribadi, pengungkapan pendapat serta pengungkapan perasaan di akun instagramnya, kedalam bentuk foto, video, maupun instastory.

Selain itu, ditemukan data bahwa responden memiliki intensitas penggunaan instagram selama 3 jam bahkan lebih dalam sehari. Responden menjelaskan bahwa mereka sering membuka instagram agar selalu mendapatkan informasi, hiburan, serta konten-konten lainnya yang dibagikan oleh orang lain. Dalam sehari mereka mampu mengupload foto/video/instastories sebanyak 3 kali. Hal ini menurut peneliti disimpulkan bahwa responden tidak bisa lepas dari instagram setiap harinya, termasuk dalam menyuarakan hal-hal yang sedang mereka lakukan serta hal yang dirasakan, terkait dengan dirinya.

Melihat fenomena tersebut, instagram dapat membuat pengguna nya kecanduan dilihat dari intensitas penggunaannya yang cukup tinggi karena terus menggunakannya khususnya dalam hal pengungkapan diri. Intensitas yang tinggi dalam pengungkapan diri di media sosial berdampak pada privasi individu yang terenggut karena informasi tentang dirinya telah menjadi rahasia publik. Hal tersebut sejalan dengan penelitian 
Paramithasari \& Dewi (2013) yang menjelaskan bahwa pengungkapan yang dilakukan di media sosial cenderung berisiko karena setiap orang dapat mengakses dan juga membaca data pribadi yang telah diungkapkan di jejaring sosial. Apalagi jika self-disclosure tersebut bersifat negatif seperti berkata kasar, mencela, atau menyinggung perasaan orang maka individu akan mendapatkan respon negatif seperti penolakan dari orang lain, dicemooh, dikucilkan, dan dihindari dari pergaulan sosial (Devito, 2011). Sebagai mana dikutip pada tribunnews.com (2018) pada kasus salah satu artis Lyra Virna, berawal dari postingan instagram yang telah melakukan pencemaran nama baik kemudian terjerat Undang-Undang Informasi dan Transaksi Elektronik (UU ITE) kepada biro pemberangkatan umrah/haji karena kekesalan yang dialami. Selanjutnya, dilansir dari detik.com (2018) menyebarkan data pribadi orang lain (doxing) di media sosial dapat terjerat UU ITE nomor 19 tahun 2016. Tentunya, penyebaran informasi seseorang tanpa mendapatkan persetujuan dari orang yang bersangkutan akan masuk dalam pelanggaran.

Dengan demikian, penting bagi individu yang memasuki dewasa awal untuk mampu mengungkapkan dirinya di media sosial Instagram secara bijaksana. Terdapat berbagai faktor yang mempengaruhi self-disclosure seseorang, diantaranya besar kelompok, perasaan menyukai/mempercayai, efek diadik, topik, budaya, gender, kepribadian serta usia (Devito,1997). Salah satu faktor yang akan peneliti teliti yaitu faktor kepribadian. Kepribadian merupakan karakter yang melekat pada diri seseorang yang bersifat unik (Suranto, 2011).

Banyak teori yang dapat menjelaskan kepribadian individu, salah satu tokoh yang menjelaskan teori kepribadian yaitu Hans Jurgen Eysenck. Menurut Eysenck, kepribadian adalah suatu keseluruhan dari pola tingkah laku aktual atau potensial dari organisme yang ditentukan oleh faktor hereditas dan lingkungan (dalam Hall \& Lindzey, 1985). Eysenck membagi kepribadian mejadi tiga tipe, yaitu tipe kepribadian ekstraversion (vs.introversion), neuroticsm, dan psychoticism (Eysenck, dalam Hall \& Lindzey, 1985).

Beberapa penelitian banyak mengaitkan kepribadian pada perilaku di media sosial. Seperti penelitian dari Anggraeni, dkk (2014) menjelaskan bahwa tipe kepribadian introvert memiliki hubungan yang signifikan dengan kecanduan internet pada siswa, karena mereka menggunakan jejaring sosial sebagai wadah mencari teman untuk bersosialisasi. Penelitian dari Widiantari \& Herdiyanto (2013) menjelaskan perbedaan intensitas komunikasi melalui jejaring sosial antara tipe kepribadian ekstrovert dan introvert pada remaja SMA di Denpasar, bahwa tipe ekstrovert mempunyai intensitas komunikasi yang lebih tinggi dibandingkan tipe introvert.

Selain itu, ada juga penelitian yang membahas bahwa kepribadian tidak memiliki korelasi dengan perilaku di media sosial, seperti contohnya penelitian yang dilakukan Maisarah \& Noviekayati (2018) mengenai hubungan tipe kepribadian ekstrovert dengan kecenderungan cyberbullying pada remaja awal pengguna media sosial Instagram, yang menjelaskan tidak ada hubungan yang signifikan diantara kedua variabel tersebut.

Pada penelitian ini, peneliti ingin meneliti lebih dalam mengenai pengaruh tipe kepribadian terhadap self-disclosure pada pengguna Instagram. Beberapa penelitian sebelumnya menjelaskan tipe kepribadian dengan perilaku pengungkapan diri pada media sosial. Studi yang dilakukan oleh Seidman (2013) terhadap mahasiswa dengan rata-rata usia 19 tahun di Amerika pengguna Facebook, bahwa ekstraversion berkaitan secara positif dengan pengungkapan emosi, karena orang yang memiliki ekstravert tinggi merasa lebih nyaman mengekspresikan perasaan mereka kepada orang lain. Menurut Ross dkk (2009) mereka yang tinggi dalam neuroticism menunjukkan minat yang kuat dalam menggunakan Internet untuk komunikasi. Neuroticism ini menggambarkan keadaan stabilitas emosi seseorang. Individu dengan kecenderungan neurotisme tinggi, cenderung mengalami emosi negatif (Ross dkk, 2009), serta memiliki dukungan sosial yang rendah (Swickert dkk, 2002) sehingga media sosial dirasa cocok untuk individu dengan kepribadian ini sebagai wadah untuk mengungkapkan informasi mengenai dirinya.

Adapun penelitian Amichai-Hamburger (2002) yang menjelaskan bahwa ekstraversion tidak berhubungan dengan pengekspresian diri, ini dikarenakan perbedaan pada konteks media yang digunakan, karena media yang digunakan pada penelitian ini didasarkan pada komunikasi chat anonim. Pada Amichai-Hamburger (2002) individu yang introvert cenderung berbagi informasi intim tentang dirinya daripada ekstrovert.

Dari penjelasan mengenai penelitian sebelumnya, terjadi perbedaan hasil penelitian dari penelitian sebelumnya dan juga self-disclosure telah diteliti kepada subjek kalangan mahasiswa atau pelajar saja. Pada penelitian ini, peneliti ingin meneliti pada subjek dewasa awal secara umum tidak pada individu yang berstatus sebagai pelajar tetapi juga pada individu yang tidak bekerja dan juga sedang bekerja. Kemudian, karena banyak pengguna instagram di Indonesia didominasi oleh individu yang memasuki usia dewasa awal yaitu sebanyak $89 \%$ penggunanya berusia 18-34 tahun, menjadi alasan peneliti lebih tertarik dengan penelitian ini. Kemudian didasarkan dengan melihat perkembangan media sosial khususnya instagram yang terus berkembang dan men- 
jadi alasan pentingnya penelitian ini dilakukan. Maka dari itu, peneliti ingin mengetahui pengaruh tipe kepribadian dari Eysenck terhadap perilaku self-disclosure pada pengguna media sosial dewasa awal khususnya instagram.

\section{METODE}

Penelitian ini, menggunakan pendekatan kuantitatif dengan desain regresi linear sederhana. Partisipan dalam penelitian ini adalah dewasa awal pengguna media sosial instagram di Kota Bandung berjumlah 400 responden. Peneliti menyebarkan kuesioner pada responden yang sesuai dengan kriteria yang telah ditentukan yaitu individu dewasa awal (18-40 tahun) di Kota Bandung yang aktif menggunakan dan mengakses media sosial instagram, melakukan aktivitas di Instagram (membuka home dan explore, melihat Instagram Story, mengunggah foto dan video, serta memberikan like dan comment pada postingan orang lain).

Pengukuran self-disclosure (self-disclosure) dalam penelitian ini diukur menggunakan skala yang diadaptasi dan disusun berdasarkan 5 aspek self-disclosure. Skala yang digunakan dalam penelitian ini yaitu Revised self-disclosure Scale (RSDS) dari Wheeless (1986) kemudian diadaptasi oleh Fitri (2017) terdiri atas 26 item setelah melakukan uji coba. Skala yang digunakan dalam penelitian ini dengan menggunakan 4 poin alternatif jawaban, berupa Sangat Setuju (SS), Setuju (S), Tidak Setuju (TS), dan Sangat Tidak Setuju (STS). Kemudian, untuk alat ukur kepribadian diukur menggunakan Eysenck Personality Questionnaire Brief Version (EPQ-BV) yang dikembangkan oleh Sato (2005) memiliki dimensi Ekstraversion dan Neuroticsm. Instrumen ini terdiri dari 24 item, dimana 12 item berkaitan dengan aspek extraversion, dan 12 item lainnya mengukur aspek neuroticsm. Instrumen EPQ-BV (Eysenck Personality Questionnaire Brief Version) menggunakan pilihan jawaban dalam bentuk 5 poin skala likert yaitu dengan skala STS (Sangat Tidak Sesuai), TS (Tidak Sesuai), N (Netral), S (Sesuai), SS (Sangat Sesuai).

Reliabilitas instrumen self-disclosure dan Eysenck Personality Questionnaire Brief version (EPQ-BV) adalah sebagai berikut:

Tabel 1. Reliabilitas instrumen self-disclosure dan Eysenck Personality Questionnaire Brief version (EPQ-BV)

\begin{tabular}{|l|c|}
\hline \multicolumn{1}{|c|}{ Variabel } & Reliabilitas \\
\hline Self-disclosure & 0.85 \\
\hline $\begin{array}{l}\text { Eysenck Personality Ques- } \\
\text { tionnaire Brief version } \\
(E P Q-B V)\end{array}$ & 0.76 \\
\hline
\end{tabular}

\section{HASIL DAN PEMBAHASAN}

Berdasarkan demografi sampel, dapat diketahui bahwa partisipan dalam penelitian ini terdiri dari laki-laki berjumlah 131 orang atau 33\% dan perempuan berjumlah 269 orang atau $67 \%$. Sehingga jumlah keseluruhan partisipan dalam penelitian ini berjumlah 400 orang. Dari data tersebut dapat diketahui bahwa jumlah partisipan perempuan lebih banyak daripada partisipan laki-laki.

Pada aspek usia diketahui bahwa responden yang berpartisipasi dalam penelitian ini cukup variatif, usia partisipan berkisar antara 18 hingga 31 tahun. Kategori usia tersebut termasuk dalam usia dewasa awal sebagaimana disusun berdasarkan penjelasan dari Hurlock (1986) yaitu dimulai dari usia 18 tahun sampai dengan 40 tahun. Dalam penelitian ini, terdapat 264 responden atau $66 \%$ dengan rentang usia 18-22 tahun, ada sebanyak 126 responden atau 32\% dengan usia 23-27 tahun, kemudian hanya 3\% responden atau sebanyak 10 orang dengan rentang usia 28-31 tahun. Dari data tersebut kita dapat mengetahui presentase responden terbanyak yaitu sejumlah 264 orang dengan rentang usia 18-22 tahun yang di dapat dari pengguna aktif instagram pada usia dewasa awal di Kota Bandung. Dari hasil penelitian ini, kita dapat mengetahui bahwa mahasiswa merupakan responden terbanyak yang berpartispasi dalam penelitian ini yaitu sebanyak 226 responden atau $57 \%$ dari total 400 responden. Kemudian, responden dengan status pekerjaan sudah bekerja sebanyak 146 atau 37\%. Sebanyak 28 responden atau 7\% merupakan responden yang belum bekerja. Kemudian, dari data demografi terdapat data intensitas penggunaan instagram pada dewasa awal di Kota Bandung, durasinya yaitu meliputi kurang dari 10 menit (1), 10-30 menit (2), 31-60 menit (3), 1-2 jam (4), 2-3 jam (5), lebih dari 3 jam (6). Dari hasil perhitungan, hanya sebanyak 21 orang $(5 \%)$ responden yang mengakses instagram selama kurang dari 10 menit dalam sehari, sebanyak 69 responden (17\%) mengakses instagram selama 10-30 menit, sebanyak 59 responden (15\%) mengakses instagram selama 31-60 menit, sebanyak 60 responden (15\%) mengakses 1-2 jam dalam sehari, 45 orang atau $11 \%$ mengakses instagram selama 2-3 jam kemudian sebanyak 146 responden (37\%) mengakses instagram selama lebih dari 3 jam. Dari hasil data demografi sampel, disimpulkan bahwa data terbanyak intensitas pengguna instagram yaitu sejumlah 146 reponden dengan intensitas lebih dari 3 jam dalam sehari setiap mengakses instagram.

Tabel 2. Hasil Uji Regresi Linear antara Tipe Kepribadian terhadap self-disclosure pada Dewasa Awal

\begin{tabular}{|l|l|l|l|l|}
\hline & $\mathbf{B}$ & $\mathbf{R}$ & $\mathbf{R 2}$ & Sig \\
\hline $\begin{array}{l}\text { Ekstraver- } \\
\text { sion }\end{array}$ & 0,159 & 0,202 & 0,041 & 0,000 \\
\hline $\begin{array}{l}\text { Neuroti- } \\
\text { cism }\end{array}$ & 0,100 & 0,157 & 0,025 & 0,002 \\
\hline
\end{tabular}


Berdasarkan hasil penelitian diketahui bahwa ing-masing dimensi tipe kepribadian extraversion dan neuroticism, keduanya memiliki pengaruh yang signifikan terhadap self-disclosure pada dewasa awal pengguna media sosial instagram. Penelitian ini mendukung teori yang telah diungkapkan oleh Devito (1997) bahwa salah satu faktor yang mempengaruhi self-disclosure adalah kepribadian. Meskipun, tipe kepribadian extraversion dan neuroticism memiliki pengaruh yang sedikit terhadap kemampuan individu untuk melakukan self-disclosure yaitu hanya sebesar 4,1\% dan 2,5\%. Maka dari itu, dapat dikatakan bahwa masih terdapat banyak faktor atau variabel lain yang dapat mempengaruhi self-disclosure seseorang selain dari tipe kepribadian.

Hasil penelitian ini menambah sudut pandang baru mengenai pengaruh self-disclosure seseorang dalam bermedia sosial khususnya pada instagram berdasarkan faktor kepribadian dari Eysenck. Eysenck (Suryabrata, 2008) menjelaskan bahwa kepribadian merupakan keseluruhan pola tingkah laku manusia yang potensial (covert) maupun aktual (overt) yang mempengaruhi perilakunya termasuk perilaku dalam mengungkapkan diri ke lingkungannya.

Berdasarkan hasil penelitian sebelumnya dari Seidman (2013) extraversion berkaitan secara positif dengan pengungkapan emosi, oleh karena itu orang yang memiliki ekstravert tinggi merasa lebih nyaman mengekspresikan perasaan mereka kepada orang lain. Seseorang yang cenderung memiliki kepribadian extrovert akan nyaman mengungkapkan berbagai hal baik impersonal maupun personal pada media sosial, masalah pribadinya, hubungan percitannya dengan orang lain (Adnan, 2018). Menurut Moore (2012) bahwa kepribadian extraversion memiliki hubungan positif dengan penggunaan jejaring sosial, karena orang dengan kepribadian ini memiliki banyak teman di media sosialnya serta lebih mungkin membuat postingan tentang kegiatan yang dilakukannya dalam sebuah status di media sosialnya. Temuan ini menunjukan bahwa extraversion terkait dengan pengungkapan pribadi seseorang seperti mengungkapkan aktivitas saat ini, pemikiran tentang minat mereka.

Dalam penelitian ini extraversion memiliki pengaruh yang signifikan terhadap self disclosure dengan nilai sig yaitu $0,000(<0,05)$. Artinya, seseorang yang memiliki kecenderungan extraversion akan cenderung juga melakukan self-disclosure pada media sosial. Akan tetapi, hasil pada penelitian ini extraversion menunjukan besaran pengaruh yang sedikit terhadap self-disclosure yaitu hanya sebesar 4,1\%. Didukung dari hasil data deskriptif, bahwa individu dengan tipe kepribadian extraversion, mayoritas dimiliki oleh responden den- gan kategori self-disclosure yang rendah yaitu sebanyak 105 responden dan yang termasuk dalam kategori self-disclosure tinggi sebanyak 93 responden serta sangat tinggi sebanyak 4 responden. Dalam penelitian ini juga, dijelaskan bahwa dewasa awal pengguna media sosial instagram yang memiliki skor extraversion yang tinggi sebanyak 209 responden atau 52\%. Individu yang memiliki kecenderungan dalam extraversion memiliki karakteristik banyak teman, sociable, suka bergaul, responsif dan membutuhkan orang lain untuk berkomunikasi (Hall \& Lindzey, 1985).

Kemudian, introversion merupakan level rendah dari extraversion. Dalam penelitian ini, responden yang memiliki skor introversion adalah sebanyak 191 responden atau $48 \%$. Individu dengan tipe intorversion cenderung memiliki nilai rendah pada self-disclosure dilihat dari kebanyakan responden dengan kategori introversion memiliki nilai self-disclosure yang rendah. Didukung dari hasil data deskriptif, responden terbanyak yaitu 127 orang yang termasuk dalam kategori self disclosure rendah dimiliki oleh responden yang cenderung introvert. Hal ini dijelaskan karena tipe kepribadian introversion cenderung rendah dalam sosiabilitas, ditandai dengan kurang pandainya bergaul, menyukai aktivitas sendiri, serta menjada jarak dari orang lain (Hall \& Lindzey, 1985). Berkaitan juga dengan penelitian yang dilakukan Widiantari dan Herdiyanto (2013) bahwa tipe kepribadian introvert mempunyai intensitas komunikasi yang lebih rendah.

Hasil analisis selanjutnya dalam penelitian ini, ditemukan bahwa individu dengan tipe kepribadian neuroticism dengan skor tinggi terdapat sebanyak 51\%. Neuroticism berhubungan dengan stabilitas emosi seseorang, jika pada asumsi sebelumnya menyatakan bahwa orang dengan level neurotisme tinggi (unstable) cenderung mengalami emosi negatif (Ross dkk, 2009), serta memiliki dukungan sosial yang rendah (Swickert dkk, 2002) sehingga media sosial dijadikan wadah untuk mengungkapkan ekspresi dirinya. Penelitian ini berkaitan dengan penelitian yang dilakukan oleh Amichai-Hamburger (2002), yaitu individu dengan neuroticsm yang tinggi mungkin memiliki kecenderungan untuk mengungkapkan informasi pribadi di jejaring sosial, dan sebagian besar disebabkan oleh kebutuhan presentasi diri (Seidman, 2013).

Menurut Ross dkk (2009) bahwa orang dengan neuroticism yang tinggi memiliki minat yang kuat juga dalam menggunakan internet untuk berkomunikasi. Dilihat dari hasil uji hipotesis bahwa neuroticism memiliki pengaruh yang signifikan terhadap self-disclosure dan memiliki nilai sig $0,002(<0,05)$. Meskipun dalam penelitian ini, menunjukan bahwa neuroticism memiliki pen- 
garuh yang kecil yaitu hanya sebesar 2,5\%. Didukung oleh data deskriptif penelitian, bahwa individu yang termasuk pada skor tinggi neuroticism (unstable) mayoritas dimiliki oleh responden yang termasuk pada kategori self-disclosure yang rendah yaitu sebanyak 113 responden, sedangkan yang termasuk pada kategori self-disclosure tinggi yaitu sebanyak 75 responden.

Selanjutnya, level rendah pada dimensi ini disebut dengan stable. Responden dengan skor neuroticism rendah (stable) terdapat sebanyak 49\% atau 197 responden. Orang dengan kecenderungan stable dimiliki oleh responden dengan self-disclosure yang rendah yaitu 119 orang. Orang yang memiliki neurotisme yang rendah cenderung memiliki ciri-ciri tenang, bergairah, dan aman (Robbins, 2001).

Menurut Eysenck, individu yang memiliki skor tinggi dalam extraversion dan neuroticism, memiliki karakteristik mudah tersinggung, tidak dapat tenang, agresif, mudah tergugah, mudah berubah-ubah pikiran, impulsive (menuruti dorongan hati), penuh harapan, dan aktif (Hall \& Lindzey, 1985). Menurut (Hall \& Lindzey, 1985), individu yang cenderung ekstrovert memiliki sosiabilitas tinggi, berani mengambil resiko, mudah terpengaruh, suasana hati cepat berubah, dan perasaannya tidak berada dibawah kontrol yang ketat. Kemudian individu yang memiliki neurotisme yang tinggi tidak stabil secara emosional, cenderung lamban dalam bertindak, kurang tetap pendirian, dan cenderung menekan hal-hal tidak menyenangkan (Suryabrata, 1982). Dengan demikian dapat dikatakan, bahwa individu dengan kepribadian extraversion-neurotic menggunakan media sosial sebagai wadah untuk mengungkapkan informasi mengenai dirinya.

Dari pembahasan diatas, media sosial tidak hanya di dominasi untuk tipe kepribadian tertentu saja. Media sosial yang ada secara luas ditargetkan untuk seluruh individu yang ingin berinteraksi serta terlibat dalam hubungan interpersonal (Harbaugh, 2010). Maka dari itu, tidak hanya orang dengan kepribadian ekstraversi saja yang dapat menggunakan fasilitas media sosial, tidak menutup kemungkinan orang dengan kecenderungan neurotik juga dapat terbuka di media sosial.

Dewasa awal yang melakukan pengungkapan diri pada media sosial instagram berupa unggahan foto/ video/insta stories yang terdiri dari lima aspek yaitu intention, amount, valence, depth/intimacy, honesty/ Accuracy. Intention merupakan keluasan individu untuk mengungkapkan tentang apa yang ingin diungkapkan. Hal tersebut menjelaskan bahwa unggahan foto/video/ insta stories mereka menujukan hal tentang informasi diri kepada teman-teman mereka di instagram . Amount merupakan dimensi yang menjelaskan kuantitas dari pe- ngungkapan diri yang dapat diukur dengan mengetahui frekuensi atau tingkat keseringan pengungkapan diri yang dilakukan individu di instagram. Hal ini terlihat dari frekuensi individu ketika mengunggah foto maupun video pada instagram berkaitan dengan kegiatan sehari-hari, perasaan, kehiduan pribadi ketika ada kesempatan.

Valence merupakan dimensi yang menjelaskan hal positif dan negatif dari perilaku pengungkapan diri dimana individu dapat menunjukkan perilaku mengenai hal-hal yang menyenangkan atau tidak menyenangkan. Ketika peneliti melakukan uji coba terhadap instrumen, responden lebih suka menceritakan hal-hal positif dan yang menyenangkan yang terjadi pada diri mereka pada instagram. Dapat dilihat dari unggahan foto/video/instastories yang mereka bagikan di instagram. Pada dimensi depth/intimacy yang menujukkan sifat pribadi yang diungkapkan individu kepada orang lain, dapat dilihat dari kedalaman seseorang dalam mengungkapkan informasi mengenai dirinya seperti percintaan, keluarga, masalah pribadi kedalam unggahan foto/video/ insta stories pada instagram. Dimensi honesty/accuracy merupakan dimensi yang menjelaskan tentang ketepatan dan kejujuran individu dalam mengungkapkan dirinya. Hal tersebut dapat dilihat dari unggahan foto/video/instastories yang mengungkapkan keadaan diri yang sebenarnya pada instagram.

Dari hasil analisis data yang diperoleh, mahasiswa merupakan partisipan paling banyak dalam penelitian ini yang menggunakan instagram secara aktif. Mahasiswa merupakan kelompok usia yang memasuki masa dewasa awal. Menurut Santrock (2002) pada masa ini, individu mulai memasuki tahap transisi, meliputi transisi secara fisik, intelektual, dan juga transisi peran sosial. Sehingga pada masa dewasa awal ini, menentukan relasi atau hubungan sangatlah penting, artinya mahasiswa perlu memiliki kemampuan hubungan dengan banyak orang serta dapat membina jaringan sosial yang baik melalui hubungan yang terjalin (Syaifussalam Wibisono, 2016). Menurut Dariyo (2016) mereka memenuhi kebutuhan untuk berafiliasi dengan cara menggunakan jejaring sosial untuk berkomunikasi secara online. Selain itu juga pada kelompok usia awal masa dewasa menurut Erikson merupakan masa seorang individu memasuki fase dimana mereka lebih sering untuk melakukan self-disclosure atau keterbukaan diri dan berbagi pikiran-pikiran personal kepada orang lain sebagai tanda sebuah keintiman (dalam Santrock, 2011).

Berdasarkan hasil penelitian pada variabel self-disclosure terhadap dewasa awal di Kota Bandung diketahui terdapat $2 \%$ atau 6 responden termasuk dalam kategori self-disclosure yang sangat tinggi, dan sebanyak 37\% 
atau 146 responden termasuk dalam kategori responden tinggi. Kemudian, responden yang tergolong dalam self-disclosure rendah adalah sebanyak 232 responden atau $58 \%$, dan yang termasuk sangat rendah sebanyak 16 responden atau 4\%. Dapat disimpulkan bahwa dewasa awal pengguna instagram di Kota Bandung mayoritas termasuk dalam kategori self-disclosure rendah. Apabila, dewasa awal yang memiliki self-disclosure yang tinggi akan merasa nyaman untuk mengungkapkan berbagai hal di dunia maya khususnya instagram dalam bentuk postingan foto/video/instastory karena keterbukaan dirinya tentang hal-hal yang personal dan impersonal. Rossen (2008) berpendapat bahwa seseorang merasa aman mengungkapkan hubungan interpersonalnya dengan orang lain di media sosial. Kemudian seseorang yang memiliki self-disclosure rendah cenderung lebih berhati-hati dalam mengungkapkan diri di media sosial, mereka hanya akan mengungkapkan diri tentang hal yang bersifat impersonal atau tentang hal tertentu saja (Widiyastuti, 2016). Pengungkapan diri termasuk dalam kegiatan yang bersifat evaluatif, yakni mengungkapkan pendapat atau perasaan individu tentang suatu hal yang disukai atau tidak disukai, Pengungkapan diri juga bersifat deskriptif, yakni mengungkapkan mengenai fakta diri sendiri kepada orang lain yang sebelumnya belum diketahui oleh lingkungan sekitar (Dayakisni, 2003).

Aspek paling tinggi yang diperoleh dewasa awal pengguna instagram yaitu mayoritas pada aspek depth/ intimacy. Artinya dalam penelitian ini dewasa awal di Kota Bandung yang menggunakan media sosial instagram untuk mengungkapkan diri dengan cara mengungkap hal-hal yang bersifat pribadi kepada orang lain, seperti mengunggah foto atau video bersama keluarga atau pasangan, aktifitas sehari-hari, mengungkapkan perasaan, pengalaman pribadi, serta hal-hal yang disukai dan tidak disukai yang mereka bagikan pada instagram. Kemudian, aspek kedua yang paling tinggi adalah Amount yaitu berkaitan dengan frekuensi individu dalam hal pengungkapan diri kepada orang lain. Dalam hal ini dapat dilihat dari tingkat keseringan individu dalam membagikan postingan apapun berkaitan tentang dirinya pada instagram.

Hasil analisis lebih lanjut dari data demografi, peneliti melakukan analisis ANOVA untuk mengetahui perbedaan berdasarkan intensitas penggunaan instagram. kemudian, terdapat perbedaan yang cukup signifikan berkaitan dengan intensitas penggunaan instagram dan self-disclosure seseorang. Dari hasil analisis yang dilakukan, terdapat nilai signifikansi senilai 0,044 $(\alpha<0,05)$. Dengan kata lain, intensitas penggunaan instagram mempengaruhi seseorang dalam melakukan self-disclosure. Dilihat dari skor rata-rata intensitas tertinggi partisipan pada instagram yaitu selama lebih dari 3 jam. Berkaitan dengan penelitian sebelumnya menyatakan bahwa semakin intensif individu menggunakan media sosial maka individu semakin terbuka untuk mengungkapkan diri (Ariani, 2018). Hal ini juga berkaitan dengan salah satu dimensi dari self-disclosure yaitu amount yang merupakan intensitas seseorang dalam melakukan self-disclosure (Wheeless, 1986). Menurut Ningsih (2015) bahwa tujuan seseorang mengungkapkan diri untuk menambah pertemanan, sebagai sarana komunikasi bahkan tempat curhat. Hal ini berkaitan dengan fenomena saat ini yang dilansir dari tekno. kompas.com (2018) bahwa rata-rata orang di Indonesia dapat menghabiskan waktu selama 3 jam 23 menit untuk mengakses media sosial. Lebih lanjut lagi, di Indonesia sendiri menjadi negara pengguna instagram terbesar seAsia Pasifik (Bohang, 2017). Dengan kata lain, bahwa responden tidak bisa lepas dari media sosial instagram setiap harinya. Hal tersebut juga berkaitan dengan pengungkapan diri individu pada instagram terutama dalam menyuarakan hal-hal yang sedang mereka alami dan dirasakan terkait dirinya sendiri, dan hal-hal yang sedang mereka lakukan.

Seseorang yang berada pada kategori self-disclosure rendah cenderung lebih selektif dalam melakukan pengungkapan diri dan cenderung menggunakan media sosial sesuai kebutuhan. Didukung oleh penelitian Widiastuti (2016) yang menjelaskan bahwa individu yang memiliki pengungkapan diri yang rendah cenderung akan lebih selektif dalam mengungkapkan dirinya di media sosial, mereka hanya akan mengungkapkan diri tentang hal-hal yang bersifat interpersonal saja. Sehingga mereka akan menyaring terlebih dahulu informasi-informasi yang akan diungkapkan, namun hal-hal yang dianggap menjadi kekurangan dirinya, hal yang dianggap tabu, aib pada dirinya umumnya cenderung tidak dibuka atau ditutupi karena muncul perasaan takut dan cemas jika masalah pribadinya diketahui oleh orang lain.

Temuan lain dari penelitian ini yaitu jenis kelamin pada dewasa awal pengguna instagram tidak memiliki perbedaan yang signifikan karena berdasarkan analisis ANOVA, tidak terdapat perbedaan yang signifikan tingkat self-disclosure dengan kategori jenis kelamin antara laki-laki dan perempuan, dengan memiliki nilai sig sebesar 0,608( $\alpha>0,05)$. Berbeda dengan teori yang diungkapkan oleh Devito (1997) bahwa salah satu faktor penentu munculnya self-disclosure adalah jenis kelamin. Hal tersebut karena semakin berkembangnya jejaring sosial sehingga semua kalangan baik laki-laki atau perempuan dapat saja menggunakan media sosial sebagai sarana untuk mengungkapkan diri kapan saja dan dimana saja melalui akun media sosialnya terutama 
instagram.

Self-disclosure dapat dipengaruhi oleh lingkungan dimana seseorang bertingkah laku. Menurut Albertia dan Emmons (2002) salah satu faktor yang mempengaruhi komunikasi seseorang adalah pendidikan. Self-disclosure sendiri merupakan salah satu bentuk komunikasi interpersonal. Namun temuan dalam penelitian ini, tidak terdapat perbedaan yang signifikan antara tingkat pendidikan dengan self-disclosure seseorang. Artinya, dalam penelitian ini tingkat pendidikan tidak mempengaruhi self-disclosure seseorang dalam mengungkapkan dirinya di media sosial. Kemudian, ditemukan bahwa status pekerjaan juga tidak memiliki perbedaan yang signifikan dengan tingkat self-disclosure. Artinya pada mahasiswa, yang sudah bekerja maupun belum bekerja memiliki tingkat self-disclosure yang sama.

Menurut Gainau (2009) bahwa keterampilan self-disclosure sebagai tingkah laku sosial dapat dipengaruhi oleh budaya, yakni budaya subjektif seperti sikap, norma, dan nilai-nilai dalam kelompok tertentu, karena keterampilan komunikasi termasuk self-disclosure dipengaruhi oleh lingkungan atau budaya di mana seseorang itu bertingkah laku. Sama halnya dengan berperilaku di media sosial, self-disclosure pada media sosial khususnya instagram dapat dipengaruhi oleh budaya. Munculnya budaya berbagi dan self-disclosure di dunia maya salah satunya merupakan dampak dari media sosial (Nasrullah, 2017), budaya ini muncul karena pada media sosial memungkinkan siapapun dapat mengunggah apapun. Pengungkapan itu menjadi suatu budaya yang pada akhirnya mengaburkan batas-batas antara ruang pribadi dan juga ruang publik (Sagiyanto \& Ardiyanti, 2018). Maka dari itu tidak hanya tipe kepribadian yang dapat mempengaruhi self-disclosure seseorang, masih terdapat banyak faktor lain yang memiliki besar pengaruh terhadap tingkat self disclsoure seseorang.

\section{SIMPULAN}

Berdasarkan penelitian yang telah dilakukan pada 400 orang dewasa awal di Kota Bandung pengguna aktif media sosial Instagram, dapat disimpulkan bahwa tipe kepribadian extraversion dan neuroticism berpengaruh pada self-disclosure seseorang di media sosial instagram namun dari masing-masing kategori hanya memiliki sedikit kontribusinya pengaruh tipe kepribadian terhadap self-disclosure. Maka dari itu, masih terdapat banyak variabel lain yang dapat mempengaruhi self-disclosure seseorang pada media sosial instagram selain tipe kepribadian seperti usia, budaya (culture), efek diadik, besar kelompok, perasaan menyukai atau mempercayai, dan topik/pembahasan.

\section{DAFTAR PUSTAKA}

Anwar, Fahmi. 2017. Perubahan dan Permasalahan Media Sosial. Jurnal Muara Ilmu Sosial, Humaniora, dan Seni. Vol. 1 (1); 137-144.

Alberti, R. dan Emmons, M., 2002. Your Perfect Right. Penterjemah Buditjahya, PT. Elex Media Komputindo, Jakarta.

APJII. (2017). Profil Penggunaan Internet Indonesia. Jakarta: APJII

Bohang, Fatimah Kartini. (2017 Juli 2017). Indonesia, Pengguna Instagram se-Asia Pasifik. Retrieved from: http:/tekno.kompas.com/ $\mathrm{read} / 2017 / 07 / 27 / 11480087 /$ indonesia-pengguna-instagram-terbesar-se-asia-pasifik (Diakses 26 Desember 2017)

Boyd, Danah M \& Ellison, B. Nicole. 2008. Social Network Sites : Definition, History and Scholarship. Journal Of Computer Mediated Communication, International Communication Association

Dariyo, A. (2016). Hubungan antara Kesepian dan Motif Persahabatan dengan Komunikasi On Line pada Remaja Akhir.

Devito, J. A. (2011). The International Communication Book Thirteen Edition. New York : University of New York

Devito, J. A. 2011. Edisi Kelima: Komunikasi Antarmanusia. Terj: Agus Maulana. Tanggerang Selatan: Karisma Publishing Group

Devito, J.A. 1986. Komunikasi antar manusia, edisi kedua. Tanggerang: Karisma Publishing Group.

Dayakisni. 2003. Psikologi Sosial. Malang : UMM.

Dayakisni. 2006. Psikologi sosial Edisi Revisi. Malang : UMM Press.

Ekasari, Nurshanti. (2013). Hubungan Antara Self-disclosure (Self-Disclosure) Melalui Blackberry Messenger dan Kualitas Hidup (Quality of Life) pada Remaja. Jurnal Ilmiah Mahasiswa Universitas Surabaya, Vol.2, No.2 (2013)

Eysenck, H.J. (1974). Dimensions of Personality. New Jersey : Transaction Publishers

Fitri, Nidatul. (2017). Hubungan Dukungan Sosial

Online dengan Pengungkapan Diri di Media Sosial Instagram pada Mahasiswa Psikologi Universitas Islam Negeri Sunan Gungung Djati Bandung. Skripsi. Universitas Islam Negeri Sunan Gun- 
gung Djati, Bandung.

Gainau, Maryam. (2009). Keterbukaan Diri (Self-disclosure) Siswa dalam Perspektif Budaya dan Implikasinya bagi Konseling. Madiun: Jurnal Ilmiah Widya Warta,. Vol 33, No 1.

Hall, C. S., \& Lindzey, G. (1985). Introduction to Theories of Personality. Canada: John Wiley \& Son.

Hamburger, Y.A., \& Ben-Artzi, E. (2000). The relationship between extraversion and neuroticism and the different uses of the Internet. Computers in Human Behavior 16:441-449.

Hurlock, Elizabeth B. 1986. Developmental Psychology. 3rd Ed, New Delhi: McGraw Hill, Inc.

Hurlock, Elizabeth B. 2003. Psikologi Perkembangan

Suatu Pendekatan Sepanjang Rentang Kehidupan, Erlangga, Jakarta.

Harbaugh, Erin Ryan. (2010). The Effect of Personality Styles (Level of Introverion-Extroversion) on Social Media Use. The Elon Journal of Undergraduate Research in Communications. Vol. 1, No. 2.

Hasan, M. Rifky. (2016). Motif

Diversi dan Self-Disclosure pada Mahasiswa Pengguna Instagram. Skripsi. Universitas Islam Indonesia,Yogyakarta.

Ifdil. (2013). Konsep Dasar Self-disclosure dan Pentingnya Bagi Mahasiswa Bimbingan dan Konseling. Jurnal Ilmiah Ilmu Pendidikan. (Nomor 1). Universitas Negeri Padang. Hlm : 110-117.

Leung. (2002). Loneliness, Self- disclosure, and ICQ

("I Seek You") Use. Cyber Psychology \& Behavior. Vol 5 (3), 241-251

Liputan6.com. (22 Mei 2012). Tujuh dari Sepuluh Orang Curhat di Jejaring. Retrieved form: https://www. liputan6.com/tekno/read/403823/tujuh-dari-sepuluh-orang-curhat-di-jejaring (diakses pada Februari 2019)

Moore, Kelly, James C. McElroy. (2012). The Influence of personality on Facebook usage, wall postings, and regret. Computers in Human Behavior. 28;267-274.

Maisarah, Dewi \& Noviekayati. (2018). Hubungan antara Tipe Kepribadian Ekstrovert dengan Kecenderungan Cybernullying pada Remaja Awal Pengguna Media Sosial Instagram. Jurnal Psikologi POSEIDON. Vol. 12 No. 1, 16-24.
Nasrullah, Rulli. (2017). Media Sosial: Perspektif Komunikasi, Budaya, dan Sosioteknologi. Bandung: Simbiosa Rekatama Media.

Ningsih, Widiyana. (2015). Self-disclosure pada Media Sosial (Studi Deskriptif Pada Media Sosial Anonim LegaTalk). (Skripsi). Program Studi Komunikasi, Universitas Sultan Ageng Tirtayasa, Banten.

Oktavianti, M. A. (2018). Instagram Stories sebagai Media Self-disclosure. (Skripsi). Fakultas Dakwah dan Komunikasi, Universitas Negeri Sunan Ampel, Surabaya.

Paramithasari, P. P., \& Dewi, E. K. (2013). Hubungan antara Kontrol Diri dengan Self-disclosure di Jejaring Sosial pada Siswa SMA Kesatrian 1 Semarang. Jurnal Empati .Vol 2, No 4

Reza, J. I. (2016, Januari 15). Wanita Lebih Doyan Main Instagram Ketimbang Pria. Liputan 6.com. Retrieved from : https://www.liputan6.com/tekno/ $\mathrm{read} / 2412338 /$ wanita-lebih-doyan-main-instagram-ketimbang-pria (Diakses 6 Agustus 2018)

Robbins, S. P. 2001. Perilaku organisasi: konsep, kontroversi, aplikasi. Jakarta: Prehalindo.

Rizkia, C. (2017, Januari 12). Geser Facebook, Instagram jadi Sosmed paling Favorit di Indonesia. Retrieved from: https://selular.id/2017/01/geser-facebook-instagram-jadi-sosmed-paling-favorit-di-indonesia/ (Diakses 8 Agustus 2018)

Ross, C., Orr, E. S., Sisic, M., Arseneault, J.M., Simmering, M.G., \& Orr, R.R. (2009). Personality and motivations associated with Facebook use. Computers in Human Behavior, 25, 578-586.

Seidman, G. (2013). Self-Presentation and Belonging on Facebook: How Personality influences social media use and motivations. Personality and Individual differences. 54, 402-407.

Sears, dkk. 1989. Psikologi Sosial Jilid 1. Jakarta: Erlangga.

Swickert, Rhonda J., Rosentreter, C. J. \& Hittner, James B. (2002). Extraversion, social support processes, and stress. Personality and Individual Differences. Vol. 32(5), 877-891

Sugiyono, 2015. Metode Penelitian Kuantitatif, Kualitatif dan R \& D. Bandung: Penerbit Alfabeta.

Suryabrata, Sumadi. (1982). Psikologi Kepribadian. Jakarta: PT. Rata Grafindo Persada. 
Suranto. 2011. Komunikasi Interpersonal. Yogyakarta; Graha Ilmu.

Sagiyanto, A. (2018). Self-disclosure melalui Media Sosial Instagram (Studi Kasus pada Anggota Galeri Quote). Journal of Communication. Vol. 2 (1) 8194

Tribunnews. (2018). Berawal dari PostinganInstagram , Kasus Pelanggaran UU ITE Lyra Virna dilimpahkan ke Kejari. Retrieved form: http:// banjarmasin.tribunnews.com/2018/10/11/berawal-dari-postingan-instagram-kasus-pelanggaran-uu-ite-lyra-virna-dilimpahkan-ke-kejarim (Diakses 6 Desember 2018)
Sato, T (2005) The Eysenck Personality Questionnaire Brief Version: FactorStructure and Reliability, The Journal of Psychology: Interdisciplinary and Applied. 139:6, 545-552, DOI: 10.3200/ JRLP.139.6.545-552

Widiyastuti, Ana. 2016. Pengaruh Tipe Kepribadian terhadap Self-disclosure (Self-disclosure) pada Pengguna Facebook Mahasiswa Fakultas Psikologi Universitas Esa Unggul.

Widiantari, K. S. \& Herdiyanto, Y. K. (2013). Perbedaan Intensitas Komunikasi melalui Jejaring Sosial antara Tipe Kepribadian Ekstrovert dan Invtrovert pada Remaja. Vol. 1 (1), 106-115 